\title{
Kepuasan Konsumen Tidak Selalu Linear dengan Loyalitas Konsumen: Analisis pada Restoran Cepat Saji di Indonesia
}

\author{
Grace Felicia Djayapranata \\ Universitas Surabaya \\ gracedj@staff.ubaya.ac.id
}

\begin{abstract}
Abstrak
Kepuasan dan loyalitas seringkali menjadi perhatian praktisi dan akademisi. Bahkan tidak jarang banyak yang menganggap bahwa konsumen yang puas pasti juga loyal dengan perusahaan sehingga perusahaan berusaha menargetkan kepuasan konsumen sebagai tujuan perusahaan. Beberapa perusahaan bahkan masih menggunakan jargon "konsumen adalah raja" yang mana pandangan ini menganggap bahwa konsumen berada di tempat tertinggi yang mana keinginan dan kebutuhan konsumen harus selalu dipenuhi agar konsumen merasa puas dan diharapkan dengan adanya kepuasan yang didapatkan, konsumen dapat loyal dengan perusahaan yang ditandai dengan pembelian kembali. Sedangkan loyalitas seringkali merupakan kunci untuk meningkatkan dan mempertahankan pangsa pasar. Dengan adanya pelanggan yang setia, maka keberlangsungan perusahaan di masa yang akan datang dapat terjamin. Memang benar bahwa kepuasan seringkali berpengaruh pada loyalitas. Namun hal ini tidak selalu demikian. Terdapat batasan antara kepuasan dengan loyalitas. Menurut Bennett dan Tiele 2004 kepuasan tidak selalu berdampak pada loyalitas, namun hal ini tergantung dari situasi dan konteksnya. Oleh karena itu, tujuan penelitian ini adalah mengetahui apakah kepuasan konsumen selalu linier dengan loyalitas konsumen. Penelitian ini merupakan penelitian deskriptif dengan menggunakan 172 responden dan dilakukan pada konteks restoran cepat saji di Indonesia. Hasil dari penelitian ini adalah kepuasan konsumen tidak selalu linier dengan loyalitas konsumen.
\end{abstract}

Kata Kunci: satisfaction, loyalty, cepat saji, strategy

\section{Pendahuluan}

Industri cepat saji merupakan industri yang berkembang dengan pesat. Salah satu yang mendorong perkembangan industri cepat saji yaitu globalisasi. Adanya globalisasi menyebabkan batas antar dunia menjadi kabur dan membawa perubahan pada aspek budaya. Budaya baru dari negara lain dapat masuk dan diadopsi sehingga membentuk suatu budaya baru. Munculnya restoran cepat saji merupakan salah satu bentuk dari adanya globalisasi. Restoran cepat saji yang mengusung budaya barat ini dengan begitu cepat menyebar dan diadopsi oleh berbagi belahan dunia sehingga menyebabkan pertumbuhan industri cepat saji menjadi begitu cepat. Bloomberg 2019 bahkan mencatat bahwa pertumbuhan industri cepat saji di dunia mencapai CAGR 4.19\%. Berita ekonomi dan bisnis 2019 bahkan menyebutkan bahwa pertumbuhan industri cepat saji di Indonesia mencapai $15 \%$ setiap tahunnya. Pertumbuhan industri yang tinggi menyebabkan industri ini menjadi salah satu industri yang memiliki pertumbuhan potensial yang baik. Potensi pertumbuhan yang baik ini juga menjadi sinyal bahwa industri cepat saji memiliki minat pembeli yang cukup tinggi. Tentunya di balik 
tingkat pertumbuhan industri yang baik terdapat 2 faktor dasar yang menyebabkan hal tersebut. Faktor tersebut adalah loyalitas dan kepuasan.

Loyalitas merupakan topik yang seringkali menjadi perhatian para pelaku usaha dan kalangan akademisi. Bagi pelaku usaha, hal ini menjadi penting karena perusahaan ingin mendapatkan profit. Memiliki pelanggan yang loyal dapat membawa dampak pada keberlangsungan perusahaan (Radovic-Markovic et al. 2017). Pertumbuhan bisnis memang tidak bisa dilepaskan dari peran pelanggan yang setia. Bahkan dalam konsep customer lifetime value, konsumen yang setia dipandang lebih menguntungkan daripada perusahaan mendapatkan pelanggan yang baru (Gupta et al. 2004, Venkatesan dan Kumar 2004). Hal ini dikarenakan untuk mendapatkan pelanggan yang baru perusahaan membutuhkan biaya yang besar untuk melakukan akuisisi konsumen. Sedangkan jika perusahaan memiliki pelanggan yang setia, perusahaan tidak memerlukan biaya yang besar untuk mendapatkan profitabilitas perusahaan. Loyalitas merupakan hal yang penting bagi perusahaan oleh karena itu perusahaan harus mengetahui faktor-faktor yang dapat membuat konsumen menjadi setia. Salah satu penyebab konsumen menjadi setia yaitu kepuasan konsumen (Naeyhun et al. 2015).

Kepuasan konsumen seringkali dipandang sebagai pusat dari kegiatan pemasaran. Kemampuan perusahaan untuk dapat menjaga kepuasan konsumen sangat penting untuk dimiliki karena konsumen yang puas, biasanya jarang melakukan komplain pada perusahaan. Secara lebih jelas, konsumen yang puas dapat dengan sukarela menyampaikan review mengenai produk/jasa yang ditawarkan perusahaan (Shi et al. 2016). Sehingga dengan banyaknya konsumen yang puas, maka konsumen secara tidak langsung dapat menjadi partner perusahaan untuk menawarkan produk atau jasa yang dijual oleh perusahaan. Selain itu, kepuasan konsumen juga seringkali dianggap sebagai goals/ tujuan perusahaan dalam menjalankan bisnis karena dengan adanya kepuasan konsumen, maka loyalitas konsumen akan didapatkan (Uddin 2019). Beberapa penelitian terdahulu telah menemukan bahwa konsumen yang puas berdampak pada loyalitas konsumen (Sahagun dan Parraga 2014). Memang benar, konsumen yang puas biasanya juga loyal. Namun hal tersebut tidak selalu terjadi. Beberapa penelitian secara kontradiktif menyebutkan bahwa kepuasan dan loyalitas tidak selalu berhubungan (Jones dan Sasser 1995; Verhoef, 2003). Padahal pembelian berulang merupakan salah satu indikator loyalitas. Lebih lanjut, Bennett dan Tiele 2004 menunjukkan bahwa kepuasan dapat berpengaruh pada loyalitas tergantung dari konteksnya. Oleh karena itu, penelitian ini ingin mengetahui apakah pelanggan yang puas akan selalu loyal. Lebih lanjut, penelitian ini merupakan penelitian deskriptif. Objek pada penelitian ini adalah restoran cepat saji.

\section{Landasan Teori :}

\section{Kepuasan}

Kepuasan pelanggan merupakan topik besar yang seringkali dibahas dalam berbagai literatur pemasaran (Manan et al. 2019; Uddin, 2019, Epinosa et al. 2018). Pemahaman ini didasarkan pada kepercayaan bahwa pelanggan harus merasa puas sehingga perusahaan mendapatkan keberlanjutan dan profitabilitas (Radovic-Markovic et al. 2017). Kepuasan pelanggan sering kali menjadi tolak ukur apakah suatu kegiatan pemasaran berhasil/tidak. Apabila pelanggan puas, maka kemungkian pelanggan untuk membeli kembali akan semakin besar dan sebaliknya. Kepuasaan pelanggan ini juga berhubungan positif dengan peningkatan profitabilitas perusahaan. Sehingga kepuasan pelanggan seringkali menjadi fokus utama para 
pengusaha. Menurut Oliver 1999, kepuasan pelanggan adalah perasaan yang timbul dari pengalaman pelanggan pada produk atau layanan yang ditawarkan perusahaan. Sedangkan menurut Yi 1991 kepuasan pelanggan adalah hasil kolektif dari persepsi, evaluasi dan reaksi psikologis terhadap konsumsi berdasarkan pengalaman dengan produk atau layanan.

Beberapa penelitian (Parasuraman, et al. 1988; Cronin dan Taylor. 1992) menganggap bahwa kepuasan secara keseluruhan sebagai fungsi utama dari kualitas layanan yang dirasakan. Pelanggan yang puas cenderung memiliki tingkat penggunaan layanan yang lebih tinggi daripada mereka yang tidak puas (Ram dan Jung 1991; Bolton dan Lemon 1999). Mereka lebih cenderung memiliki niat dan untuk membeli kembali yang lebih kuat merekomendasikan produk / layanan kepada kenalan mereka (Zeithaml et al., 1996). Banyak penelitian juga mengungkapkan bahwa kepuasan pelanggan secara positif mempengaruhi loyalitas (Bloemer et al. 1999, Oliver 1999, Zeithaml et al. 1996).

\section{Loyalitas}

Mempertahankan dan meningkatkan jumlah pelanggan yang setia sangat penting dilakukan untuk mencapai keberlangsungan perusahaan dalam jangka panjang (Han dan Hyun 2018). Kesetiaan pelanggan biasanya disebut dengan loyalitas pelanggan. Oliver 1999 mendefinisikan loyalitas sebagai

"komitmen yang dipegang teguh untuk membeli kembali layanan pilihan secara konsisten di masa depan dan karenanya menyebabkan pembelian pada penyedia layanan atau produk yang sama secara berulang-ulang, terlepas dari pengaruh situasional dan upaya pemasaran yang berpotensi menyebabkan perilaku penggantian (switching behavior)"

Menurut Oliver ( 1999, 1997) terdapat empat fase kesetiaan, yang mana setiap tahapan memiliki jenjang yang berbeda:

Tahap pertama merupakan kesetiaan kognitif, yang berbasis tentang informasi faktual seperti adanya keunggulan yang fungsional seperti pada aspek manfaat, biaya dan kualitas. Selain itu, loyalitas pada tahap ini biasanya lebih menekankan loyalitas pada merek karena dalam suatu merek terdapat atribut informasional. Namun loyalitas pada tahap ini merupakan loyalitas yang paling dangkal karena tidak memperhitungkan kepuasan serta hanya memperhatikan sisi atribut informasional saja yang mudah berubah. Sedangkan loyalitas yang memperhitungkan kepuasan terdapat pada fase berikutnya yaitu fase loyalitas afektif.

Tahap kedua yaitu loyalitas afektif: Pada fase loyalitas afektif hubungan loyalitas yang terjadi merupakan hubungan yang lebih kuat daripada level kognisi saja karena pada level ini loyalitas didapatkan dari hasil informasi (level kognisi) dan kepuasan konsumen sebagai hasil didapatkan dari hasil evaluasi konsumen. Munculnya aspek loyalitas di tahap ini dikarenakan adanya kepuasan yang menimbulkan kesukaan dan menjadikan produk/jasa yang ditawarkan. Tahap ketiga adalah fase konatif. Pada fase ini merupakan fase yang lebih kuat daripada fase afektif karena pada fase ini sudah menunjukkan niat atau komitmen untuk melakukan tindakan, sedangkan pada fase afektif, hanya menunjukkan kecenderungan secara motivasional saja. Pengukuran pada fase ini biasanya pada aspek keinginan untuk melakukan pembelian berulang. Tahap yang keempat yaitu fase konatif. Pada fase ini, niat untuk melakukan tindakan berkembang menjadi perilaku sehingga fase ini merupakan fase yang paling kuat dalam 
pengukuran loyalitas. Pada fase ini konsumen tidak mudah untuk melakukan perubahan perilaku (switching behavior) .

Secara sederhana, pengukuran loyalitas dapat dilihat dari (1) sikap, (2) perilaku, dan (3) gabungan antara sikap dan perilaku. Loyalitas sikap mencerminkan komitmen terhadap merek dan komitmen untuk membeli kembali merek, sedangkan loyalitas perilaku mengacu pada perilaku pembelian berulang konsumen, seperti yang tercermin dalam pola pembelian konsumen secara berkelanjutan yang dapat terlihat dari pengeluaran aktual.

\section{Metode Penelitian}

Metode self administered survey digunakan dalam penelitian ini melalui kuesioner. Penelitian ini difokuskan di Indonesia karena tingkat pertumbuhan industri cepat saji di Indonesia yang cukup besar. Beberapa data menunjukkan bahwa tingkat pertumbuhan industri cepat saji di Indonesia cukup tinggi yaitu sebesar $15 \%$ per tahun (Richard 2019)

Penyebaran kuesioner dilakukan secara daring dikarenakan masih dalam masa pandemi Covid 19 yang mengharuskan orang untuk tetap menjaga social distancing. Pemilihan sampling dilakukan dengan metode judgmental sampling yaitu dengan menetapkan beberapa kriteria yaitu 1. pernah membeli dan makan di resto cepat saji, 2. melakukan pembelian lebih dari 1x dalam setahun. Terdapat 2 variabel pada penelitian ini yaitu kepuasan dan loyalitas. Kepuasan secara operasional didefinisikan sebagai hasil kolektif dari persepsi pada pengalaman yang didapatkan pada saat mengonsumsi produk /jasa pada restoran cepat saji. Sedangkan loyalitas didefinisikan sebagai komitmen untuk tetap melakukan pembelian berulang secara konsisten di restoran cepat saji.

Penelitian ini merupakan penelitian deskriptif dengan menggunakan split half by mean. Metode ini merupakan pendekatan untuk mengestimasi reliabilitas dari test score ketika data yang dikumpulkan hanya berupa data administrasi (Warrens 2015). Dengan metode ini setiap variabel dinilai berdasarkan hasil mean setelah itu, dari hasil mean setiap variabel dilakukan split data berdasarkan hasil mean hasilnya adalah variabel kepuasan terdiri atas puas dan tidak puas, serta variabel loyalitas terdiri atas tidak loyal dan loyal. Setelah data terbagi atas 2, lalu dilakukan crosstab dengan SPSS 23

\section{Pembahasan}

Berdasarkan penelitian yang dilakukan, didapatkan data responden seperti pada Tabel 1.

Tabel 1. Data Responden

\begin{tabular}{|l|l|l|}
\hline Nama restoran & Frekuensi & Persentase \\
\hline A\&W & 8 & 4,7 \\
\hline Burger King & 7 & 4,1 \\
\hline KFC & 39 & 22,7 \\
\hline McD & 118 & 68,6 \\
\hline $\begin{array}{l}\text { Frekuensi Kunjungan } \\
\text { dalam setahun }\end{array}$ & & \\
\hline$<5$ kali & 40 & 23,3 \\
\hline 5-10 kali & 64 & 37,2 \\
\hline
\end{tabular}




\begin{tabular}{|l|l|l|}
\hline$>10$ kali & 68 & 39,5 \\
\hline Jenis Kelamin & & \\
\hline Perempuan & 84 & 48,8 \\
\hline Laki-laki & 88 & 51,2 \\
\hline Usia & & \\
\hline 18-26 tahun & 141 & 82,2 \\
\hline 27-35 tahun & 18 & 10,5 \\
\hline $36-44$ tahun & 10 & 5,8 \\
\hline $45-53$ tahun & 0 & 0 \\
\hline $54-62$ tahun & 3 & 1,7 \\
\hline Pekerjaan & & \\
\hline Ibu Rumah Tangga & 1 & 0.6 \\
\hline Karyawan Swasta & 29 & 16,9 \\
\hline Mahasiswa & 136 & 79,1 \\
\hline Profesional & 3 & 1,7 \\
\hline Wiraswasta & 3 & 1,7 \\
\hline $\begin{array}{l}\text { Jenjang } \\
\text { Terakhir }\end{array}$ & & \\
\hline SMA & 134 & \\
\hline D3 & 3 & 77,9 \\
\hline S1 & 27 & 1,7 \\
\hline S2 & 8 & 15,7 \\
\hline S3 & 0 & 4,7 \\
\hline Pengeluaran/ bulan & & 0 \\
\hline <Rp. 1000.000,- & 29 & \\
\hline Rp 1.000.000 - 1.999.999,-- & 62 & 16.9 \\
\hline Rp 2.000.000 - 2.999.999,- & 44 & 36 \\
\hline Rp 3.000.000 - 3.999.999,-- & 13 & 25,6 \\
\hline Rp 4.000.000 - 4.999.999,- & 4 & 7,6 \\
\hline$>$ Rp 5.000.000,- & 20 & 2 \\
\hline & & 11,6 \\
\hline
\end{tabular}

Sumber: data diolah, 2020

Dari hasil pengumpulan data didapatkan sebanyak 172 responden, 52,2\% responden berjenis kelamin pria, dan 48,8\% responden berjenis kelamin wanita. Dari responden yang terkumpul Sebanyak 39,5\% responden pernah melakukan kunjungan sebanyak $>10$ kali, sebanyak 37,2\% responden melakukan kunjungan sebanyak 5-10 kali, dan sebanyak 23,3\% responden melakukan kunjungan sebanyak $<5$ kali. Sedangkan restoran cepat saji yang paling sering dikunjungi adalah McD dengan 68,6\% responden, KFC dengan responden sebanyak $22,7 \%$, A\&W dengan responden sebanyak 4,7\%, dan Burger King dengan responden sebanyak 4,1\%. Jenjang pendidikan terakhir responden terbanyak yaitu SMA sebanyak 77,9\%, D3 sebanyak 1,7 \% responden, S1 sebanyak $15,7 \%$ responden, dan $\mathrm{S} 2$ sebanyak 4,7\%. responden. Pekerjaan responden sebagian besar adalah mahasiswa sebanyak $79,1 \%$ responden, karyawan swasta $16,9 \%$ responden, profesional $1,7 \%$ responden, wiraswasta $1,7 \%$ dan ibu rumah tangga sebanyak 0,6\% responden. Pengeluaran responden dalam sebulan < Rp. 1.000.000,- sebanyak $16.9 \%$, pendapatan Rp 1.000.000 - 1.999 .999 sebanyak $36 \%$, Rp 2.000.000- 2.999.999 sebanyak 25,6 \%, Rp 3.000.000- 3.999.999 sebanyak 7,6 \%, Rp 4.000.000-4.999.999 sebanyak $2 \%$ dan >Rp. 5.000.000 sebanyak 11,6\%. 
Grace Felicia Djayapranata

Tabel 2. Data Deskriptif

\begin{tabular}{|l|l|l|}
\hline Variabel & Mean & Deviasi Standar \\
\hline Kepuasan & 5,546 & 1,666 \\
\hline Loyalitas & 5,360 & 1,307 \\
\hline
\end{tabular}

Sumber: data diolah, 2020

Berdasarkan Tabel 2 rata-rata/mean kepuasan konsumen di restoran cepat saji sebesar 5,546 Hal ini berarti bahwa rata-rata konsumen merasa puas dengan produk/jasa yang ditawarkan pada restoran cepat saji. Selain itu deviasi standar pada variabel kepuasan sebesar 1,666. Sedangkan untuk variabel loyalitas mendapat nilai mean sebesar 5,360 yang berarti bahwa konsumen memiliki loyalitas yang cukup tinggi pada restoran cepat saji. Deviasi standart variabel loyalitas adalah sebesar 1,307

Tabel 3. Kepuasan dan Loyalitas di Restoran Cepat Saji

\begin{tabular}{|l|l|l|l|}
\hline \multirow{3}{*}{ Kepuasan } & & \multicolumn{2}{|c|}{ Loyalitas } \\
\cline { 2 - 4 } & & Tidak loyal & Loyal \\
\cline { 2 - 4 } & Rendah & 54 atau 31,40\% & 16 atau 9,30\% \\
\cline { 2 - 4 } & Tinggi & 23 atau 13,37\% atau 45,93\% & \\
\hline
\end{tabular}

Sumber: data diolah, 2020

Tabel 3 menunjukkan bahwa terdapat 4 jenis kelompok konsumen yaitu konsumen yang merasa puas dan loyal dengan jumlah sebanyak 45,93\%, kelompok kedua yaitu kelompok konsumen yang tidak puas dan tidak loyal sebanyak 31,40\%, kelompok ketiga yaitu kelompok yang puas namun tidak loyal yaitu sebanyak $13,37 \%$ dan konsumen yang merasa tidak puas namun loyal sebanyak 9,30\%. Konsumen merasa kualitas layanan yang diberikan tinggi dan konsumen loyal. Tentu saja sebagai pihak pengelola restoran cepat saji sangat mengharapkan bahwa banyak konsumen yang puas dan loyal dengan perusahaan. Namun kenyataan nya, masih terdapat konsumen yang tidak puas dan tidak loyal. Selain itu, dari tabel tersebut, terdapat dua fenomena yang menarik yaitu (1) terdapat segmen yang tidak puas namun loyal, dan (2) fenomena konsumen yang puas namun tidak loyal. Alasan mengapa konsumen tidak puas, namun loyal yaitu Konsumen membeli produk karena orang lain. Keputusan pembelian konsumen tidak selalu didasarkan pada diri sendiri. Keputusan pembelian konsumen dapat dipengaruhi oleh orang lain misalnya oleh keluarga, teman dan lain sebagainya (Hawkins dan Motherbaugh, 2010). Misalnya keputusan pembelian baju. Walaupun pembelian baju sering kali merupakan keputusan yang dibuat oleh end user, namun keputusan ini tidak selalu didasarkan pada kebutuhan orang tersebut. Seorang konsumen yang belum memiliki anak, bisa saja membeli baju anak-anak untuk keponakan, atau anak temannya. Sama seperti pada kasus dalam penelitian ini, bahwa konsumen dapat merasa tidak puas namun loyal. Hal ini kemungkinan disebabkan karena dalam keputusan pembelian tersebut, konsumen membelikan produk untuk orang lain, ataupun konsumen dapat menjadi pelanggan yang loyal suatu restoran hanya karena diajak oleh teman/ keluarga/ lain sebagainya. 
Selain itu, dari Tabel 3 dapat terlihat bahwa kepuasan konsumen tidak selalu linier dengan loyalitas konsumen. Hal ini sejalan dengan penelitian Bennett dan Thiele 2004 bahwa kepuasan konsumen tidak selalu berujung pada loyalitas, namun hal ini tergantung dari konteksnya. Pada penelitian ini, konteks penelitian yang diambil yaitu restoran cepat saji. Ada beberapa alasan bahwa persaingan yang tinggi dapat menyebabkan kepuasan tidak berdampak pada loyalitas.

Pertama, persaingan yang tinggi menyebabkan perusahaan menjadi semakin kompetitif. Di Industri cepat saji, banyaknya pemain yang masuk ke dalam industri menyebabkan semakin ketatnya persaingan dalam industri ini. Kim dan Mauborgne (2005) menyebutkan bahwa persaingan yang ketat dalam industri menyebabkan perusahaan masuk ke dalam red ocean. Red ocean merupakan situasi persaingan yang berdarah-darah karena persaingan yang terjadi dalam suatu pasar sangat ketat. Persaingan yang ketat menyebabkan margin profit yang dihasilkan akan semakin kecil. Dengan ketatnya persaingan, maka setiap perusahaan yang ada dalam pasar ini akan berlomba-lomba melakukan berbagai cara untuk dapat menang. Hal ini juga terjadi pada restoran cepat saji seperti $\mathrm{KFC}, \mathrm{McD}$, Burger King, dan lain sebagainya. restoran cepat saji menerapkan strategi harga yang kompetitif, bahkan tak jarang juga mereka secara reguler akan memberikan diskon-diskon dengan harga yang kompetitif untuk memenangkan pasar. Disatu sisi, dengan adanya hal tersebut konsumen akan merasa diuntungkan dan puas karena merasa bahwa produk yang dibeli memiliki manfaat yang lebih besar bila dibandingkan dengan biaya yang dikeluarkan. Namun disisi lain, dengan adanya penerapan strategi seperti ini akan memunculkan perilaku konsumen yang baru yaitu perilaku konsumen yang hanya membeli karena adanya diskon. Konsumen yang tergolong dalam jenis ini tentu saja hanya akan membeli produk yang ditawarkan hanya ketika perusahaan memberi potongan harga. Perilaku pembelian dalam kasus ini tentu tidak dapat mendorong kepada perilaku loyal, walaupun konsumen merasakan kepuasan.

Kedua, industri cepat saji dipandang belum memiliki superior value. Pada industri yang memiliki persaingan yang cukup tinggi, penting bagi perusahaan untuk memiliki value yang unik agar konsumen dapat loyal. Value yang unik dalam Porter's Five Forces (Cravens dan Percy, 2013) merupakan salah satu komponen yang dapat membuat switching cost menjadi semakin tinggi. Dengan adanya switching cost yang tinggi, membuat konsumen berpikir ulang apabila konsumen ingin berpindah ke pesaing. Dengan demikian, maka loyalitas konsumen dapat tercapai. Namun kenyataanya, industri cepat saji dipandang belum memiliki value yang unik. Hal ini dapat terlihat dari produk yang disajikan antar pesaing. Produk yang ditawarkan antara satu restoran dengan restoran yang lain hampir sama yaitu ayam goreng yang mana rasa ayam goreng yang disajikan tiap restoran hampir sama. Hal ini menyebabkan, konsumen dengan mudah dapat berpindah ke pesaing sehingga loyalitas akan susah untuk didapatkan.

Ketiga, kepuasan superior sulit untuk dicapai. Menurut Jones dan Sasser 1995 menjelaskan bahwa terdapat 2 jenis loyalitas yaitu loyalitas yang asli (jangka panjang) dan loyalitas palsu. Ada beberapa hal yang dapat menyebabkan loyalitas konsumen merupakan loyalitas yang palsu misalnya regulasi pemerintah untuk membatasi persaingan, kepemilikan teknologi tertentu, diskon dan lain sebagainya. Regulasi pemerintah misalnya pembatasan jumlah persaingan membuat konsumen tidak memiliki banyak opsi atas produk/jasa yang akan dibeli, sehingga konsumen mau atau tidak mau membeli produk yang ditawarkan perusahaan. Sedangkan loyalitas yang asli adalah loyalitas yang memiliki dampak pada jangka panjang. Konsumen yang termasuk memiliki loyalitas yang asli ini biasanya memiliki ciri-ciri memiliki keinginan yang tinggi untuk melakukan pembelian berulang, dengan senang hati merekomendasikan 
produk, bahkan konsumen bersedia menjadi brand advocate perusahaan (Schepers dan Nijssen 2018). Namun, loyalitas yang berdampak jangka panjang hanya dapat dicapai jika konsumen merasakan kepuasan yang superior (Goldstein 2009). Kotler 2015 membagi kepuasan menjadi 2 jenis yaitu satisfied dan delight. Kepuasan yang superior termasuk dalam kategori delight yang mana kepuasan pada jenis ini sangat susah untuk dicapai. Untuk mencapai posisi ini, perusahaan harus melakukan sesuatu yang lebih dari ekspektasi konsumen. Pada penelitian ini, konsumen diberikan skala penilaian 1-7 yang mana hasil rata-rata penilaian di bawah 4 artinya konsumen tidak puas dan jika diatas 4 artinya konsumen merasa puas. Ketika konsumen menilai bahwa dirinya merasa puas, hal ini hanya berarti bahwa apa yang dilakukan perusahaan sudah sesuai dengan ekspektasi, namun belum dapat melihat bahwa kepuasan yang didapatkan merupakan kepuasan yang superior atau tidak. Lebih lanjut, untuk mencapai kepuasan konsumen yang superior yang dapat memberi pengaruh positif pada loyalitas jangka panjang, biasanya perusahaan harus dapat memberikan sesuatu yang diluar dari ekspektasi misalnya pelayanan dengan sentuhan personal seperti mengingat nama pelanggan, dan lain sebagainya. Selain itu, biasanya kepuasan yang superior hanya bisa dicapai ketika perusahaan benar-benar memahami konsumen seperti mengetahui preferensi konsumen, nilai, atau masalah yang dihadapi konsumen. Hal ini membutuhkan perusahaan yang dapat mendengarkan dan memahami konsumen. Dengan kata lain, untuk membuat konsumen merasakan kepuasan yang superior, perusahaan harus dapat benar-benar menangkap apa yang menjadi kebutuhan dan keinginan target konsumen secara spesifik. Sejauh ini pelayanan yang diberikan restoran cepat saji hanya standart karena restoran cepat saji hanya berfokus pada pemberian pelayanan yang mengutamakan kecepatan, namun tidak berfokus pada pemberian pelayanan yang mengutamakan customer experience. Serta mereka tidak memiliki target konsumen yang spesifik. Dengan adanya pelayanan yang standar, kepuasan superior sulit untuk dicapai. Selain itu, Konsumen membutuhkan variasi. Konsumen bisa puas, namun konsumen tidak loyal karena konsumen membutuhkan variasi. Walaupun konsumen puas dan senang dengan produk maupun layanan yang diberikan, terkadang konsumen dapat bosan dengan menu yang diberikan oleh restoran apalagi keputusan pembelian dalam makanan cepat saji merupakan termasuk dalam keterlibatan yang rendah dikarenakan produknya yang murah sehingga konsumen tidak terlbat secara aktif mencari informasi oleh karena itu konsumen dapat berpindah ke tempat lain untuk mencari variasi menu atau sekedar mencari suasana baru.

\section{Kesimpulan:}

Pada penelitian terdapat dua fenomena menarik yaitu konsumen yang tidak puas dapat loyal dan konsumen yang puas belum tentu loyal. Pada kasus konsumen tidak puas namun loyal hal ini bukan berarti bahwa orang yang tidak puas tidak selalu berarti bahwa mereka tidak akan melakukan pembelian berulang, karena keputusan pembelian konsumen tidak selalu dipengaruhi oleh diri sendiri, melainkan pembelian konsumen dapat dipengaruhi oleh orang lain misalnya oleh orang tua, teman, pacar dan lain sebagainya.

Fenomena menarik lainnya adalah kepuasan tidak selalu berujung pada loyalitas. Kepuasan didapatkan dari hasil pengalaman dan interaksi konsumen dengan perusahaan yang dalam hal ini adalah restoran cepat saji. Pada industri cepat saji, persaingan yang dihadapi sangatlah kompetitif sehingga masing-masing industri akan berlomba-lomba untuk memenangkan pasar misalnya dengan memberikan diskon. Hal ini tentunya akan memberikan kepuasan pada konsumen, namun level kepuasan yang didapatkan hanya sekedar puas atau memenuhi ekspektasi dan kepuasan yang seperti ini tidak akan mendorong pada kepuasan yang superior. Selain itu, restoran cepat saji dipandang belum memiliki nilai yang unik, sehingga 
belum dapat menciptakan switching cost yang tinggi. Hal ini yang sering kali menyebabkan konsumen mudah untuk berpindah ke pesaing. Kepuasan yang superior susah untuk dicapai pada restoran cepat saji karena untuk mendapatkan kepuasan yang superior yang berdampak pada loyalitas jangka panjang konsumen perlu untuk mendapatkan hal yang lebih dari sekedar merasa puas misalnya dengan sentuhan personal. Menurut penelitian Nobar 2018 menemukan bahwa pelayanan yang berorientasi pada pengalaman pelanggan dapat berdampak pada tercapainya kepuasan yang superior. Selain itu, untuk mendapatkan kepuasan yang superior perusahaan harus benar-benar memahami apa yang menjadi keinginan dan kebutuhan serta permasalahan yang dihadapi oleh konsumen yang spesifik. Akan tetapi, pada restoran cepat saji, hal yang menjadi fokus utama pengelola yaitu kecepatan pelayanan sehingga pelayanan yang diberikan hanya standart serta mereka tidak menarget suatu kelompok konsumen yang spesifik, sehingga kepuasan yang superior sulit untuk didapatkan. Dengan adanya hal ini,maka kepuasan konsumen yang didapat tidak akan berdampak pada loyalitas dalam jangka panjang.

Implikasi dari hal tersebut yaitu pengelola harus berfokus untuk dapat menjaga loyalitas konsumen, bukan hanya berfokus pada kepuasan konsumen. Untuk menjaga agar konsumen loyal, perusahaan harus memiliki nilai yang unik sehingga konsumen merasa biaya penggantian yang dirasakan konsumen cukup besar sehingga konsumen tidak mudah untuk berpindah. Penciptaan nilai yang unik dapat dilakukan dengan menawarkan suasana yang nyaman yang berbeda dengan yang lain, selain itu perusahaan juga dapat meningkatkan nilai dari sentuhan personal pada tiap konsumen untuk dapat menciptakan pengalaman pelanggan yang berkesan bagi konsumen sehingga dapat mencapai kepuasan yang superior.

\section{Daftar Pustaka}

Bennett, R, \& Thiele.R. S (2004) "Customer satisfaction should not be the only goal". Journal of services marketing 2 (18): 7

Bloemer, J. K., de Ruyter, \& Peeters. P (1998). "Investigating Drivers of Bank Loyalty: The Complex Relationship Between Image, Service Quality and Satisfaction”. International Journal of Bank Marketing, 16, pp. 276-286

Bloomberg. (2019). Fast Food Market to Reach \$931.7Bn, Globally, by 2027 at 4.6\% CAGR: Allied Market Research. diakses dari www. Fast Food Market to Reach \$931.7Bn, Globally, by 2027 at 4.6\% CAGR: Allied Market Research - Bloomberg.com pada 27 November 2020

Bolton, R.N. \& Lemon, K.N (1999) “A Dynamic Model of Customers’ Usage of Services: Usage as an Antecedent and Consequence of Satisfaction". Journal of Marketing Research, 36, 171-186. https://doi.org/10.2307/3152091

Cravens, D.W. \& Piercy N.F (2013) Strategic Marketing (10 ${ }^{\text {th }}$ edition). Singapore: McGrawHill Companies, Inc

Cronin, J.J \& Taylor, S.A (1992) "Measuring Service Quality: A Reexaminataion and Extension", Journal of Marketing, June (56): 55-68.

Epinosa. J. A., OrtinauI. D.J., Krey. N., \& Monahan.L. (2018) 'I'll have the usual: how restoran brand image, loyalty, and satisfaction keep customers coming back". Journal of Product \& Brand Management, 27(6): 599-614 
Goldstein, S. D. (2009) Superior Customer Satisfaction and Loyalty: Engaging Customers to Drive Performance, Wisconsin: ASQ Quality Press.

Gupta, S., Lehmann, D.R., \& Stuart, J.A (2004) "Valuing customers". Journal of Marketing Research, 41 (1): 7-18.

Han, H., \& Hyun, S. S. (2018) "Role of motivations for luxury cruise traveling, satisfaction, and involvement in building traveler loyalty". International Journal of Hospitality Management, 70: 75-84.

Hawkins, D.I., \& Mothersbaugh, D.L. (2010) Consumer Behavior: Building Marketing Strategy ( $11^{\text {th }}$ edition). Irwin: McGraw-Hill

Jones, T.O. \& Sasser, W.E. Jr (1995), "Why satisfied customers defect", Harvard Business Review, Vol 73 :88-99.

Kim, W. C. \& Mauborgne, R (2015) Blue Ocean Strategy: How to Create Uncontested Market Space and Make the Competition Irrelevant. Amerika: Harvard Business School Publishing

Kotler, P. \& Keller, K.L (2015) Marketing Management (15 th Edition). Pearson Education,Inc

Mannan. M., Chowdhury. N., Sarker. P., \& Amir. R (2019) "Modeling customer satisfaction and revisit intention in Bangladeshi dining restorans". Journal of Modelling in Management 14 (4): 922-947

Naehyun (Paul) J., Nathaniel D. L \& Merkebu, J (2015) "The Impact of Brand Prestige on Trust, Perceived Risk, Satisfaction, and Loyalty in Upscale restorans", Journal of Hospitality Marketing \& Management, DOI: 10.1080/19368623.2015.1063469

Nobar, H.B.K (2018). "The impact of customer satisfaction, customer experience and customer loyalty on brand power: Empirical evidence from hotel industry". Journal of Business Economics and Management 19 (2):417-430 DOI: 10.3846/jbem.2018.5678

Oliver, R. L. (1997) Satisfaction A Behavioral Perspective On The Consumer. Singapura: McGraw-Hill Education.

Parasuraman, A., Zeithaml, V.A.and Berry, L.L. (1998) "SERVQUAL: a multiple item scale for Measuring consumer perceptions of service quality", Journal of Retaling 64 (10): $12-40$.

Radovic-Markovic, M., Farooq. S, M., \& Markovic, D (2017) "Strengthening the resilience of small and medium-sized enterprises". Rev. Appl. Socio Econ. Res.345-356.

Ram, S., \& Jung, H (1991) "How product usage influences consumer satisfaction”. Market Lett 2: 403-411 . https://doi.org/10.1007/BF00664226

Richard. M (2019). Bisnis Restoran cepat saji Berpeluang Tumbuh 15\% Tahun Ini di akses dari: www. Bisnis Restoran cepat saji Berpeluang Tumbuh 15\% Tahun Ini - Ekonomi Bisnis.com Pada 27 November 2020 
Sahagun, M. A \&Parraga, A. Z (2014) "Can fast-food consumers be loyal customers, if so how? Theory, method and findings", Journal of retailing and consumer services (21) :168-174

Schepers, J. \& Nijssen, E. J (2018) "Brand advocacy in the frontline: how does it affect customer satisfaction?", Journal of Service Management 29(2), 230-252. https://doi.org/10.1108/JOSM-07-2017-0165

Shi-W., Tang-L, Zhang-X.H, Gao-Yu., \& Zhu- Y. (2016) "How does word of mouth affect customer satisfaction?". Journal of Business \& Industrial Marketing 3(3): 393-403,

Uddin, M. B., (2019)" Customer loyalty in the fast food restorans of Bangladesh", British Food Journal (121): 11

Venkatesan, R., \& Kumar, V., (2004) “A customer lifetime value framework for customer selection and resource allocation strategy". Journal of Marketing 68(4): 106- 125

Verhoef, P (2003) "Understanding the effect of customer relationship management efforts on customer retention and customer share development", Journal of Marketing, Vol. $67: 30-45$.

Warrens M.J. (2015) “On Cronbach's Alpha as the Mean of All Split-Half Reliabilities”. Quantitative Psychology Research. doi.org/10.1007/978-3-319-07503-7_18

Yi, Y (1991). “A Critical Review of Consumer Satisfaction. In V. A. Zeithaml (Ed.)”, Review of Marketing.

Zeithaml, V.A., Berry, L.L. and Parasuraman, A (1996), "The behavioral consequences of service quality", Journal of Marketing 60 (2): 31-46 